\title{
Suppression of IL-8 production from airway cells by tiotropium bromide in vitro
}

This article was published in the following Dove Press journal:

International Journal of COPD

2 September 201 I

Number of times this article has been viewed

\author{
Isao Suzaki' \\ Kazuhito Asano ${ }^{2}$ \\ Yusuke Shikama ${ }^{3}$ \\ Taisuke Hamasaki' \\ Ayako Kanei' \\ Harumi Suzaki' \\ 'Department of Otorhinolaryngology, \\ School of Medicine, Showa University, \\ Tokyo, Japan; ${ }^{2}$ Division of Physiology, \\ School of Nursing and Rehabilitation \\ Sciences, Showa University, Yokohama, \\ Japan; ${ }^{3}$ Department of Respiratory \\ Diseases, Showa University Northern \\ Yokohama Hospital, Yokohama, Japan
}

Correspondence: Kazuhito Asano Division of Physiology, School of Nursing and Rehabilitation Sciences, Showa University, Midori-ku, Yokohama 226-8555, Japan

$\mathrm{Tel}+8 \mid 459856538$

Fax +8I 459857583

Email asanok@med.showa-u.ac.jp
Background: COPD is characterized by persistent and progressive airway inflammation. Although neutrophilic airway inflammation is generally accepted to be a major factor in the pathogenesis of COPD, the influence of the agents used for the treatment of COPD on neutrophil functions such as chemotaxis is not fully understood.

Purpose: The present study aimed to examine the influence of tiotropium bromide on the production of interleukin (IL)-8 from human airway epithelial cells and lung fibroblasts (LFs) after lipopolysaccharide (LPS) stimulation in vitro.

Methods: BEAS-2B cells, human bronchial epithelial cell line, and LFs, at a concentration of $5 \times 10^{5}$ cells $/ \mathrm{mL}$, were stimulated with LPS in the presence of various concentrations of tiotropium bromide. IL- 8 in culture supernatants was examined by enzyme-linked immunosorbent assay (ELISA). IL-8 messenger ribonucleic acid (mRNA) expression was examined by real-time polymerase chain reaction. The influence of tiotropium bromide on LPS-induced signaling pathways was also analyzed by examining nuclear factor-kappa (NF- $\kappa)$ B activation and signaling protein phosphorylation by ELISA.

Results: Tiotropium bromide at $>15 \mathrm{pg} / \mathrm{mL}$ inhibited IL- 8 production from both BEAS-2B cells and LFs after LPS stimulation. Tiotropium bromide also suppressed IL-8 mRNA expression through the inhibition of NF- $\mathrm{KB}$ activation and signaling protein, extracellular-signal-regulated kinase $1 / 2$, and c-Jun N-terminal kinase, phosphorylation.

Conclusion: The present results strongly suggest that tiotropium bromide exerts the inhibitory effect on neutrophilic inflammation through the suppression of IL-8 production from epithelial cells and LFs by interfering with LPS-mediated signaling pathways and thus may contribute to lower cellular inflammation in COPD, which is responsible for favorable modification of the disease.

Keywords: IL-8, suppression, tiotropium bromide, airway cells, in vitro

\section{Introduction}

COPD includes severe clinical conditions characterized by progressive airflow limitation. ${ }^{1}$ The pathophysiology of airways in COPD involves neutrophilic airway inflammation, protease - antiproteases imbalance, and oxidative stress. ${ }^{2}$ Airway inflammation in COPD can be demonstrated by examination of sputum. ${ }^{2,3}$ Sputum from smokers and ex-smokers with COPD contained a much higher number of neutrophils than sputum from those without COPD, and increased neutrophils are associated with rapid decline in forced expiratory volume in 1 second $\left(\mathrm{FEV}_{1}\right) .{ }^{4}$ It is also observed that the levels of myeloperoxidase and lactoferrin, which are the neutrophil activation makers, are elevated in the sputum from COPD patients. ${ }^{2,5}$ Although these reports strongly indicate that neutrophils are active 
participants in airway inflammation in COPD, the influence of the agents used for the treatment of COPD on neutrophil functions such as chemotaxis is not well defined.

Anticholinergic agents have been proven to be of particular value in the treatment of COPD, as vagal cholinergic tone appears to be the only reversible component of airway narrowing. ${ }^{6}$ Anticholinergics block muscarinic receptors located on airway smooth muscle cells and possibly on submucosal gland cells, and prevent smooth muscle contraction and mucus secretion, thus producing a bronchodilatory effect. ${ }^{6}$ Tiotropium bromide, an anticholinergic bronchodilator, has a quaternary ammonium structure and is derived from that of ipratropium bromide. ${ }^{7}$ It has been clearly shown that tiotropium bromide was approximately 10 -fold more potent than ipratropium in binding to cloned human muscarinic receptors expressed on Chinese hamster ovary cells. The apparent binding affinity of tiotropium bromide and ipratropium was similar for M1, M2, and $\mathrm{M} 3$ receptors, but kinetic studies showed that tiotropium bromide dissociated 100 times more slowly than ipratropium from M1 and M3. ${ }^{7}$ From these pharmacological studies, tiotropium bromide is recommended as the first-choice agent in the treatment of COPD. ${ }^{8}$

Interleukin (IL)-8, a member of the CXC chemokine family, is known to be produced by macrophages and other cells such as epithelial cells and fibroblasts. It is also recognized that IL- 8 is involved in the development of several human conditions including wound repair, angiogenesis, and COPD. ${ }^{9}$ The primary function of IL- 8 is the induction of chemotaxis in neutrophils and lymphocytes. The elevation of IL-8 in sputum levels in studies of stable COPD $^{10,11}$ and the significant correlations between IL-8 levels in sputum and COPD severity as judged by $\mathrm{FEV}_{1}{ }^{12}$ have been reported. Tiotropium bromide is reported to reduce neutrophil chemotaxis induced by the supernatant from alveolar macrophage stimulated with lipopolysaccharide (LPS) through the suppression of tumor necrosis factor- $\alpha$ production. However, the precise mechanisms are not well defined. ${ }^{13}$ In the present study, therefore, we examined the influence of the muscarinic receptor antagonists on IL-8 production from epithelial cells through the choice of tiotropium bromide, the most common muscarinic receptor antagonist, and an in vitro cell culture technique.

\section{Materials and methods \\ Chemicals}

Tiotropium bromide was kindly donated from Nippon Boehringer Ingelheim Co, Ltd (Tokyo, Japan) as a preservativefree pure powder. The powder was dissolved in Dulbecco's
Modified Eagle's Medium/Ham's Nutrient Mixture F-12 (DMEM/F-12) medium (Sigma-Aldrich, Inc, St Louis, MO; MEDIUM) at a concentration of $10.0 \mu \mathrm{g} / \mathrm{mL}$. This solution was then sterilized by passing it through $0.2 \mu \mathrm{m}$ filters and stored at $4^{\circ} \mathrm{C}$ as stock solution until used. All dilutions used in this study were prepared from this stock solution by diluting it with MEDIUM. LPS extracted from Escherichia coli (Sigma-Aldrich, Inc) was dissolved in MEDIUM at a concentration of $10.0 \mathrm{mg} / \mathrm{mL}$. It was then sterilized by passing it through a $0.2 \mu \mathrm{m}$ filter and diluted with MEDIUM at $3.0 \mu \mathrm{g} /$ mL. SP-600125, a c-Jun N-terminal kinase (JNK)-II inhibitor, PD-98059, a mitogen-activated protein kinases/extracellularsignal-related kinase (MAPK/ERK), which is an upstream kinase of ERK1/2, inhibitor, and SB-203580, a p38 MAPK inhibitor, were purchased from Calbiochem (La Jolla, CA). These chemicals were first dissolved in dimethyl sulfoxide at $1 \mathrm{mM}$, then diluted with MEDIUM at $10 \mu \mathrm{M}$, filtered through $0.2 \mu \mathrm{m}$ filters, and used for experiments.

\section{Cell line}

The human bronchial epithelial cell line BEAS-2B cells were purchased from American Type Culture Collection (Manassas, VA) and cultured in small airway cell basal medium $\left(\mathrm{SABM}^{\circledR}\right)$ that contained growth factors for epithelial cells (Lonza Co, Ltd, Walkersville, MD). The cells were used between the 45 th and 55 th generation passages.

\section{Cell source and induction of fibroblasts}

Tissue samples from patients without lung fibrosis or COPD were obtained from healthy tissue area during pneumonectomy for tumor resection from a tumor-free area. All donors (three female, 43-71 years; two male, 41 and 71 years) were given a written informed consent, which was approved by the Ethics Committee of Showa University Yokohama Northern Hospital. Cells were induced from tissues according to the methods described previously. ${ }^{13}$ Briefly, the diced tissue specimens (approximately $1 \mathrm{~mm}^{2}$ ) were plated at a density of 10 pieces in 100-mm tissue culture dishes and covered with a microscope slide that adhered to the dishes. The dishes were then placed in a humidified atmosphere containing $5 \% \mathrm{CO}_{2}$ at $37^{\circ} \mathrm{C}$. When a monolayer of fibroblast-like cells was found to be confluent, the explanted tissues were removed. The cells were then trypsinized, and replated at a concentration of $5 \times 10^{5}$ cells $/ \mathrm{mL}$ into $100-\mathrm{mm}$ tissue culture dishes with a final volume of $10.0 \mathrm{~mL}$. Subsequently, the cells were split $1: 2$ at confluence and passaged. The cells were characterized according to the methods described previously, ${ }^{14}$ and the fibroblast purity was more than $99 \%$ and used as lung-derived 
fibroblasts (LFs). LFs at 5 to 6 passages were used for the experiments.

\section{Cell culture}

BEAS-2B cells were washed several times with MEDIUM and introduced into each well of 24-well culture plates in triplicate at a concentration of $5 \times 10^{5}$ cells $/ \mathrm{mL}$. After 12 hours, cells were treated with LPS and various concentrations of tiotropium bromide in a final volume of $2.0 \mathrm{~mL}$. After 24 hours, the culture supernatants were removed, and stored at $-40^{\circ} \mathrm{C}$ until used. To examine transcription factor activation and messenger ribonucleic acid (mRNA) expression, BEAS-2B cells were cultured in a similar manner for 4 hours and stored at $-80^{\circ} \mathrm{C}$ until used. To prepare cells to examine signaling protein phosphorylation, BEAS-2B cells were cultured in a similar manner with 96-well flatbottomed culture plates for 30 minutes. In experiments using LFs as target cells, LFs suspended in RPMI-1640 medium supplemented with $10 \%$ fetal calf serum (RPMI-FCS) were cultured in a similar manner to that used for BEAS-2B cells. In all cases, tiotropium bromide was added to cell cultures 2 hours before the stimulation with LPS.

\section{Assay for IL-8}

IL-8 levels in culture supernatants were examined by the commercially available human IL-8 enzyme-linked immunosorbent assay (ELISA) kits (R \& D Systems, Inc, Minneapolis, $\mathrm{MN}$ ) according to the manufacturer's recommendation.

\section{Real-time polymerase chain reaction (RT-PCR)}

IL-8 mRNA expression in both BEAS-2B cells and LFs were examined by RT-PCR according to the methods described previously. ${ }^{14}$ Oligonucleotide sequences of the primers used are shown in Table 1.

\section{Assay for transcription factor activation}

Nuclear factor-kappa (NF- $\kappa)$ B activity in cultured cells was analyzed by commercially available NF- $\kappa$ B ELISA test kits (Active

Table I Primer sequences used for RT-PCR

\begin{tabular}{ll}
\hline Primer sequences & $\begin{array}{l}\text { Product } \\
\text { size, bp }\end{array}$ \\
\hline IL-8 & 289 \\
Sense: 5'-ATGACTTCCAAGCTGGCCGTGGCT-3' & \\
$\quad$ Antisense: 5'-TCTCAGCCCTCTTCAAAAACTTCTC-3' & \\
$\beta$-actin & 239 \\
Sense: 5'-ACCCACACTGTGCCCATCTA-3' & \\
Antisense: 5' -CGGAACCGCTCATTGCC-3' & \\
\hline
\end{tabular}

Motif, Carlsbad, CA) that contained sufficient reagents and monoclonal antibodies against p50 and p65, in accordance with the manufacturer's recommended procedures. In brief, nuclear extract (5.0 $\mu \mathrm{g}$ protein) from cells was introduced into each well of 96-well microplates pre-coated with oligonucleotide containing the NF- $\kappa \mathrm{B}$ consensus site ( $5^{\prime}$-GGGACTTTCC- $3^{\prime}$ ) in a volume of $20.0 \mu \mathrm{L}$, and incubated for 1 hour at $25^{\circ} \mathrm{C}$. After washing three times, $100 \mu \mathrm{L}$ of monoclonal antibody against p50 and p65 was added to the appropriate wells, and incubated for a further 1 hour at $25^{\circ} \mathrm{C}$. Anti-IgG horseradish peroxidase (HRP)-conjugate in a volume of $100 \mu \mathrm{L}$ was then added and incubated for 1 hour at $25^{\circ} \mathrm{C}$. The absorbance at $450 \mathrm{~nm}$ was measured after the addition of tetramethylbenzine solution.

\section{Assay for signaling protein phosphorylation}

Phosphorylation of signaling proteins, ERK1/2, p38 MAPK, and JNK, was analyzed with commercially available ELISA kits (Active Motif) according to the manufacturer's recommendation. In brief, cells treated with LPS and tiotropium bromide were fixed with $4 \%$ formaldehyde for $20 \mathrm{~min}$ utes at $25^{\circ} \mathrm{C}$. After washing the plate, the primary antibody against phosphorylated-ERK1/2, p38 MAPK, or JNK was added into each well at a volume of $40 \mu \mathrm{L}$ and incubated for 12 hours at $4^{\circ} \mathrm{C}$. After removing the antibody by washing, $100 \mu \mathrm{L}$ of HRP-conjugated secondary antibody was added. After 1 hour at $25^{\circ} \mathrm{C}$, tetramethylbenzyne solution was added at a volume of $100 \mu \mathrm{L}$ per well and the absorbance at $450 \mathrm{~nm}$ was measured followed by the addition of $2 \mathrm{~N} \mathrm{HCl}$.

\section{Statistical analysis}

The statistical significance of the difference between control and experimental data was analyzed using a one-way analysis of variance (ANOVA) test by using GraphPad Prism 5 (GraphPad Software Inc, San Diego, CA). A $P$ value $<0.05$ was accepted as statistically significant.

\section{Results}

\section{Suppressive activity of tiotropium} bromide on IL-8 production from cells after LPS stimulation

The first two experiments were designed to examine the influence of tiotropium bromide on LPS-induced IL-8 production from airway cells. BEAS-2B cells were stimulated with $1.0 \mu \mathrm{g} / \mathrm{mL}$ LPS in the presence or absence of tiotropium bromide for 24 hours, and IL-8 levels in culture supernatants were assayed by ELISA. Although the addition of tiotropium 
bromide at concentration $<10.0 \mathrm{pg} / \mathrm{mL}$ could not inhibit the ability of cells to produce IL- 8 in response to LPS stimulation, tiotropium bromide at $12.5 \mathrm{pg} / \mathrm{mL}$ significantly suppressed LPS-induced IL- 8 production from BEAS-2B cells (Figure 1A). The data in Figure 1A also show that tiotropium bromide at concentration $>15.0 \mathrm{pg} / \mathrm{mL}$ could completely inhibit IL-8 production from BEAS-2B cells in response to LPS stimulation: experimental culture supernatants contained similar levels of IL-8 to control culture supernatant. We then examined the influence of tiotropium bromide on LPS-induced IL-8 production from LFs. As shown in Figure 1B, tiotropium bromide also inhibited the ability of cells to produce IL-8 in response to LPS stimulation. The minimum concentration that caused significant suppression of IL-8 production was $15.0 \mathrm{pg} / \mathrm{mL}$ (Figure 1B).

\section{Suppressive activity of tiotropium bromide on IL-8 mRNA expression in cells after LPS stimulation}

The third experiment was undertaken to examine the influence of tiotropium bromide on LPS-induced IL-8 mRNA expression in both BEAS-2B cells and LFs. BEAS-2B cells and LFs were stimulated with $1.0 \mu \mathrm{g} / \mathrm{mL}$ LPS in the presence of various concentrations of tiotropium bromide for 4 hours, and IL-8 mRNA expression was examined by RT-PCR. As shown in Figure 2A, the addition of tiotropium bromide at concentration $>12.5 \mathrm{pg} / \mathrm{mL}$ significantly inhibited IL-8 mRNA expression, which was increased by LPS stimulation. Tiotropium bromide also inhibited
IL-8 mRNA expression in LFs induced by LPS stimulation. The minimum concentration of tiotropium bromide that caused significant inhibition of IL-8 mRNA expression in LFs was $15.0 \mathrm{pg} / \mathrm{mL}$ (Figure 2B).

\section{Suppressive activity of tiotropium bromide on transcription factor activation in cells after LPS stimulation}

The fourth experiment was designed to examine the influence of tiotropium bromide on transcription factor, NF- $\kappa \mathrm{B}$, activation in both BEAS-2B cells and LFs. These cells were stimulated with $1.0 \mu \mathrm{g} / \mathrm{mL}$ LPS in the presence of various concentrations of tiotropium bromide for 4 hours, respectively. The nuclear extract was prepared, and NF- $\kappa \mathrm{B}$ activity was assessed by measuring p50 and p65 activity by ELISA. As shown in Figure 3, the addition of tiotropium bromide at concentration $>12.5 \mathrm{pg} / \mathrm{mL}$ significantly suppressed p50 and p65 activation in BEAS-2B cells, which was increased by LPS stimulation. Figure 3 also shows the suppressive activity of tiotropium bromide on NF- $\kappa \mathrm{B}$, p50 and p65, activation induced by LPS stimulation in LFs (Figure 4). The minimum concentration that caused significant suppression was $15.0 \mathrm{pg} / \mathrm{mL}$ (Figure 4A and B).

\section{Suppressive activity of tiotropium bromide on signaling protein phosphorylation}

The fifth experiment was carried out to examine the influence of tiotropium bromide on signaling protein phosphorylation in both BEAS-2B cells and LFs after LPS stimulation.
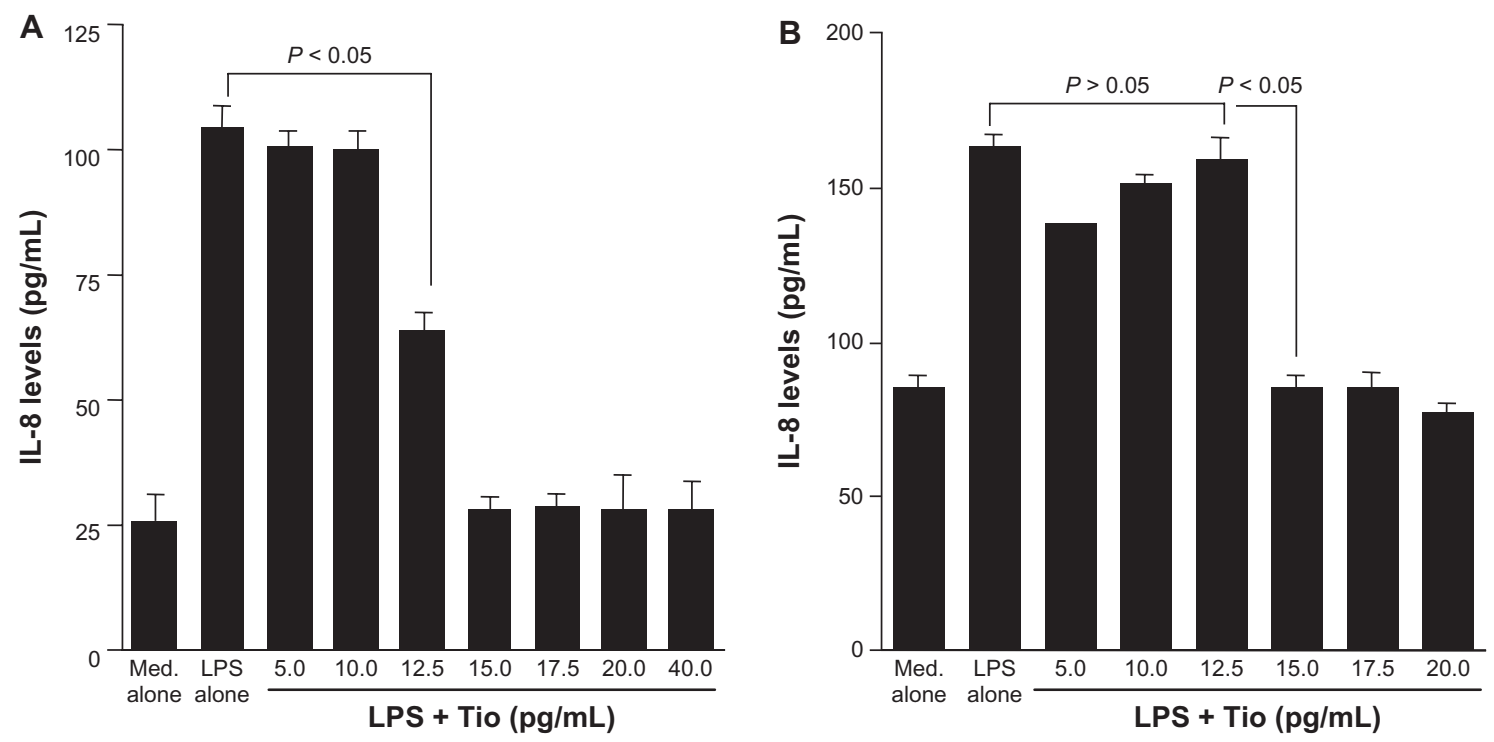

Figure I Suppressive activity of tiotropium bromide (Tio) on IL-8 production from BEAS-2B cells (A) and lung fibroblasts (B) after lipopolysaccharide (LPS) stimulation. Cells $\left(5 \times 10^{5}\right.$ cells $\left./ \mathrm{mL}\right)$ were stimulated with $1.0 \mu \mathrm{g} / \mathrm{mL}$ LPS in the presence of various concentrations of Tio for 24 hours. IL-8 levels in culture supernatants were examined by ELISA. The data are expressed as the mean $\mathrm{pg} / \mathrm{mL} \pm$ SE of five different subjects. 

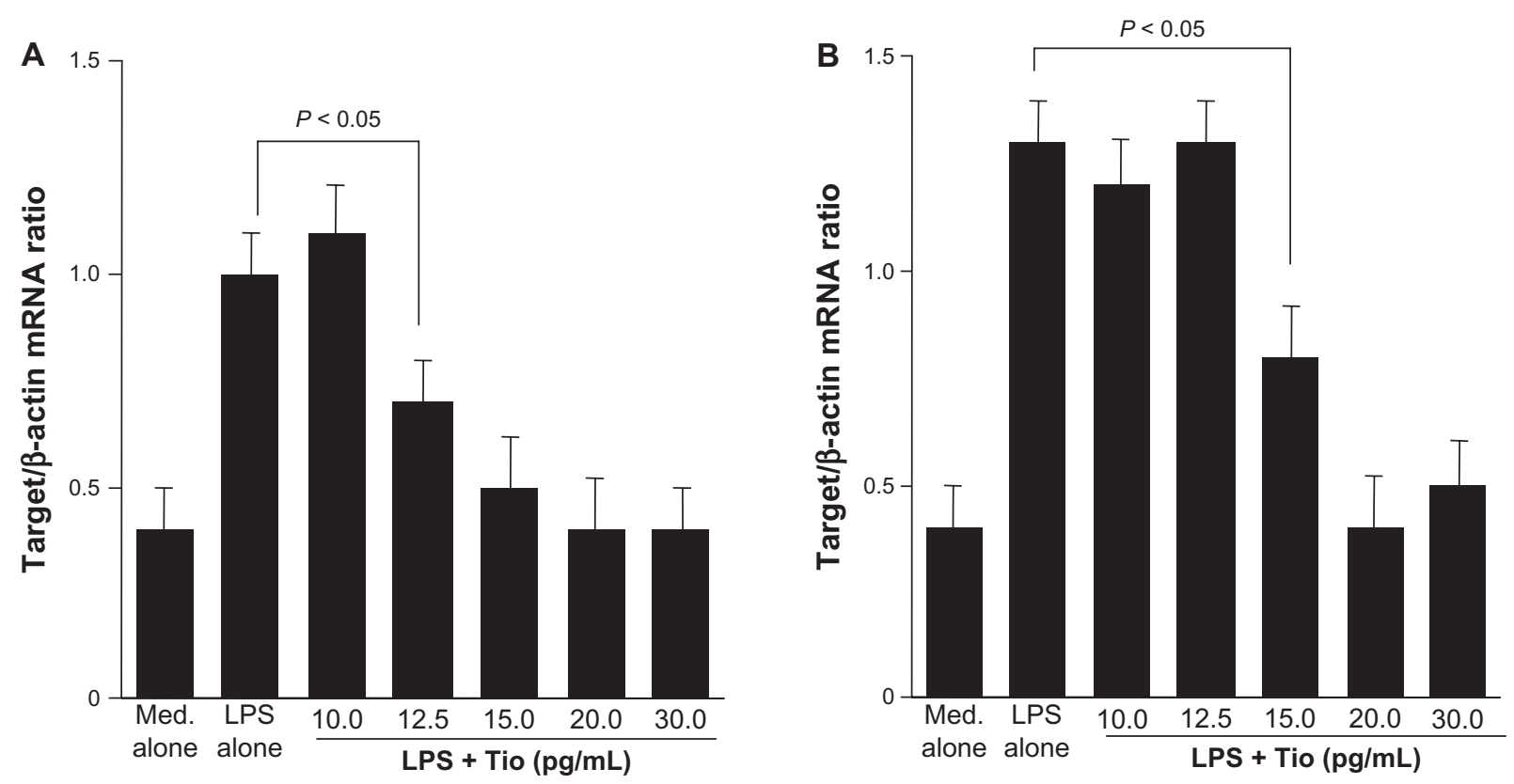

Figure 2 Suppressive activity of tiotropium bromide (Tio) on IL-8 mRNA expression in BEAS-2B cells (A) and lung fibroblasts (B) after lipopolysaccharide (LPS) stimulation. Cells $\left(5 \times 10^{5}\right.$ cells $\left./ \mathrm{mL}\right)$ were stimulated with $1.0 \mu \mathrm{g} / \mathrm{mL}$ LPS in the presence of various concentrations of Tio for 4 hours. IL-8 $\mathrm{mRNA}$ expression was examined by RT-PCR. The data are expressed as the mean ratio \pm SE of 5 different subjects.

The cells were cultured with $1.0 \mu \mathrm{g} / \mathrm{mL}$ LPS in the presence of various concentrations of tiotropium bromide for 30 minutes. Signaling protein phosphorylation, p38MAPK, ERK1/2, and JNK, was examined by ELISA. Treatment of BEAS-2B cells with tiotropium bromide at concentration $>12.5 \mathrm{pg} / \mathrm{mL}$ significantly inhibited the phosphorylation of ERK1/2 and
JNK but not p38 MAPK, which was enhanced by LPS stimulation (Figure 5A, B and C). Tiotropium bromide also significantly suppressed the phosphorylation of ERK1/2 and JNK but not p38MAPK in LPS-treated LFs, when cells were treated with tiotropium bromide at concentration $>15.0 \mathrm{pg} / \mathrm{mL}$ (Figure 6A, B and C).
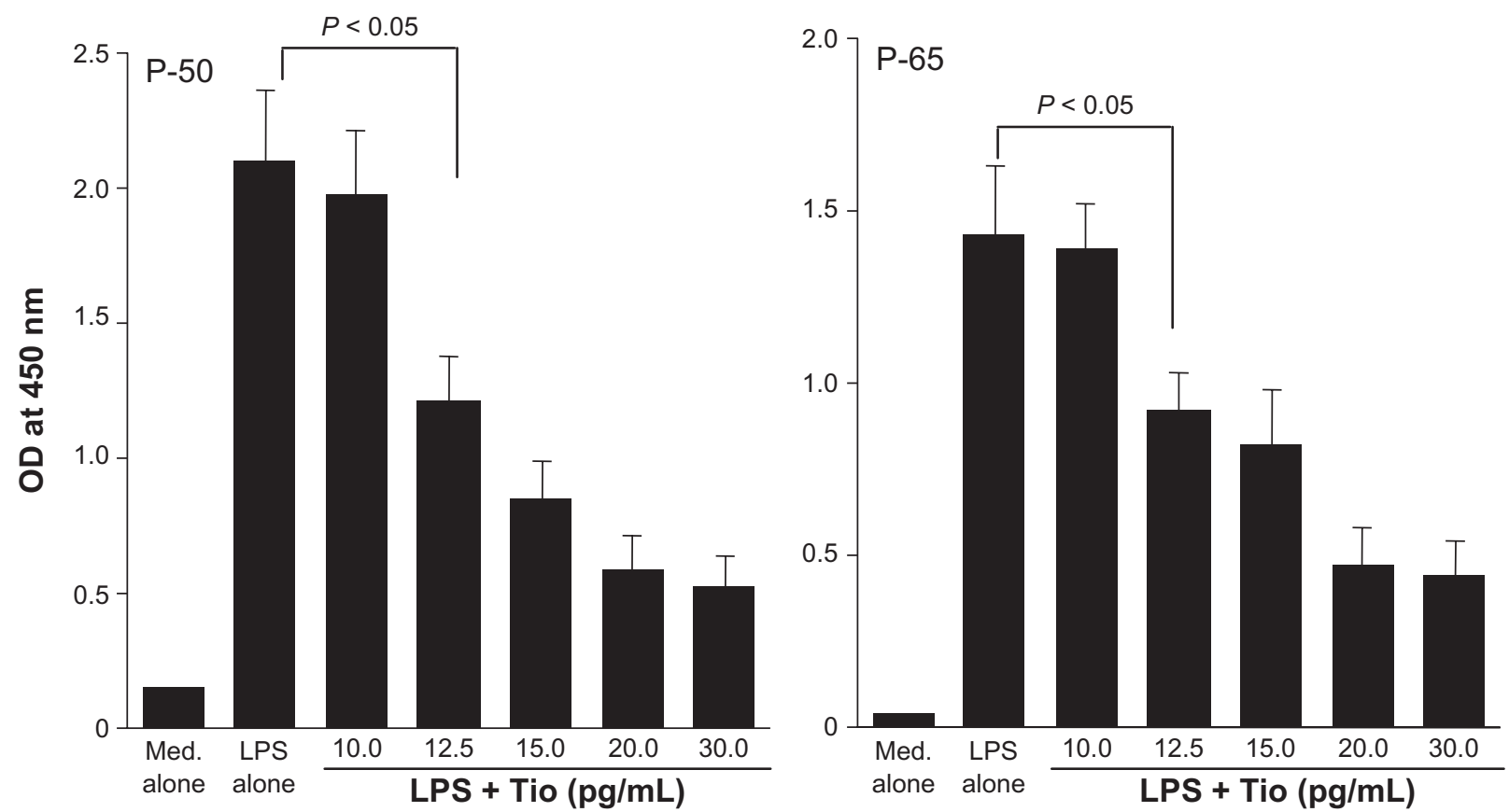

Figure 3 Suppressive activity of tiotropium bromide (Tio) on NF- $\kappa B$ activation in BEAS-2B cells after lipopolysaccharide (LPS) stimulation. Cells ( $5 \times 10^{5}$ cells $/ \mathrm{mL}$ ) were stimulated with $1.0 \mu \mathrm{g} / \mathrm{mL}$ LPS in the presence of various concentrations of Tio for 4 hours. NF- $\mathrm{KB}, \mathrm{p} 50$ and p65, activation was examined by ELISA. The data are expressed as the mean optical density (OD) at $450 \mathrm{~nm} \pm \mathrm{SE}$ of five different subjects. 

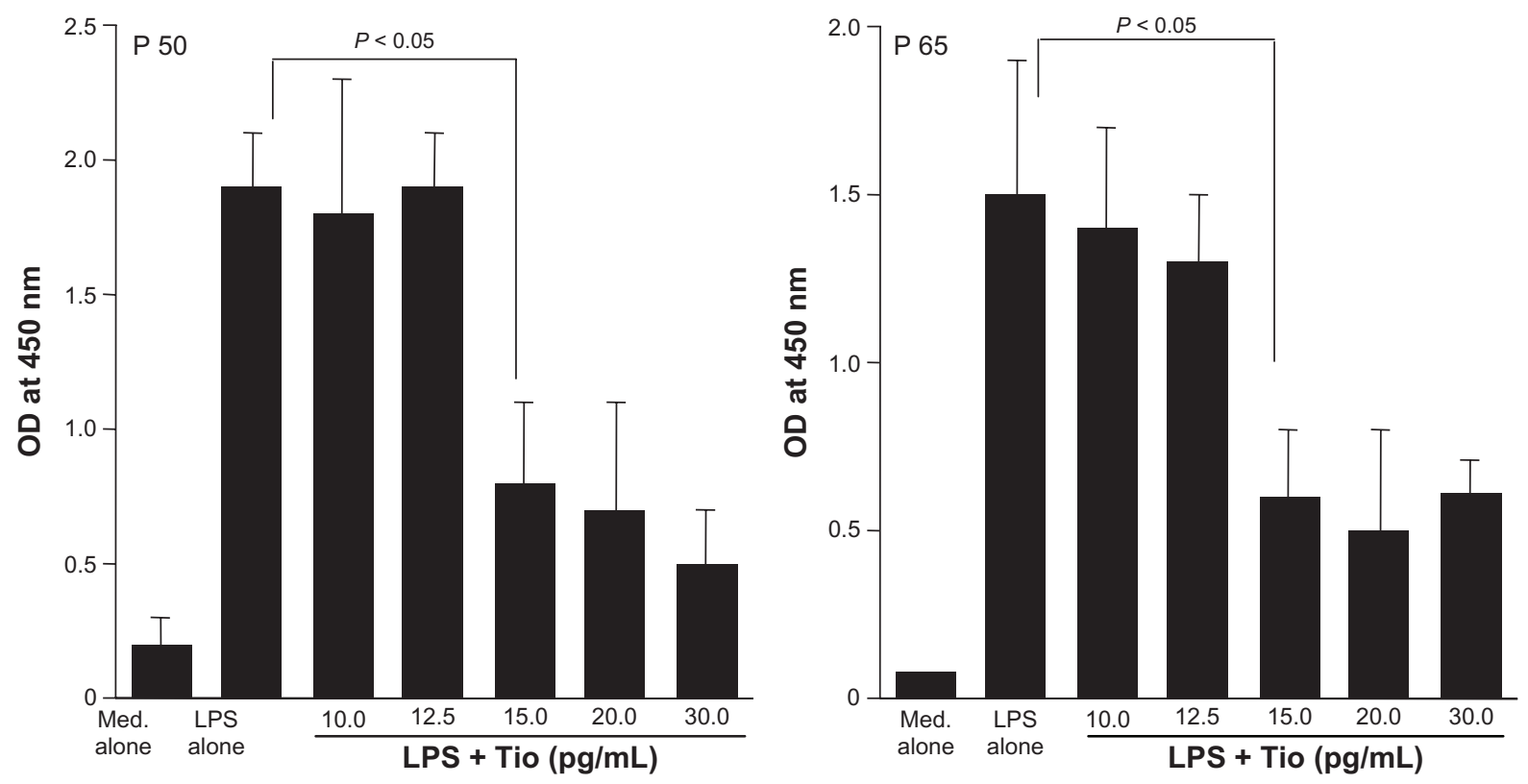

Figure 4 Suppressive activity of tiotropium bromide (Tio) on NF- $\kappa$ B activation in lung fibroblasts after lipopolysaccharide (LPS) stimulation. Cells $\left(5 \times 10^{5}\right.$ cells/mL) were stimulated with $1.0 \mu \mathrm{g} / \mathrm{mL}$ LPS in the presence of various concentrations of Tio for 4 hours. NF- $\mathrm{KB}, \mathrm{p} 50$ and p 65 , activation was examined by ELISA. The data are expressed as the mean optical density (OD) at $450 \mathrm{~nm} \pm \mathrm{SE}$ of five different subjects.

\section{Effect of kinase inhibitors on IL-8 production from cells after LPS}

\section{stimulation}

The final experiment was performed to examine the role of signaling pathways regulating IL-8 production from both BEAS-2B cells and LFs after LPS stimulation. The cells were treated with kinase inhibitors, SP-600125, PD-98059, and SB-203580, 30 minutes before LPS stimulation. The culture supernatants were obtained after 24 hours and IL-8 levels were examined by ELISA. Pretreatment of cells, BEAS-2B (Figure 7A) and LFs (Figure 7B), with SP-600125 scarcely affected IL-8 production after LPS stimulation. On the other hand, pretreatment of cells with PD-98059 and SB-203580 significantly suppressed IL-8 production from both BEAS-2B cells (Figure 7A) and LFs (Figure 7B).

\section{Discussion}

The present results clearly show that tiotropium bromide at concentration $>15 \mathrm{pg} / \mathrm{mL}$, which is extremely low compared with therapeutic blood levels, ${ }^{15}$ could suppress IL-8 production from airway epithelial cells and LFs. In addition, this inhibitory action of tiotropium bromide on IL-8 production is due, in part, to its suppressive effect on IL-8 mRNA expression through the inhibition of both transcription factor, NF- $\mathrm{kB}$, activation and signaling protein phosphorylation, especially ERK1/2 and JNK, induced by LPS stimulation.
IL-8 is involved in several human diseases such as inflammation, angiogenesis, cancer metastasis, and COPD. ${ }^{16-18}$ The primary function of IL- 8 is also accepted to be the induction of chemotaxis in its target cells, especially neutrophils. ${ }^{9}$ Besides inducing chemotaxis, IL-8 is able to induce an increase in cytosolic calcium, which is essential for exocytosis (eg, mediator release), and respiratory burst. ${ }^{9}$ Increased number of cells of the innate immune system is one important characteristic of inflammation in COPD. ${ }^{18}$ There are mostly neutrophils, which are attracted as a result of mediator release by activated epithelial cells and resident cells of the monocyte/macrophage lineage at the alveoli and the small conducting airways. ${ }^{2,19,20}$ It has been suggested that chemokines, which attract neutrophils, act directly on fibroblasts and smooth muscle cells and promote airway remodeling observed in COPD. ${ }^{20}$ In addition, it is also reported that neutrophils infiltrated into airways and alveoli are activated to release neutrophil mediators such as myeloperoxidase and neutrophil lipocalin, which correlate broadly with disease severity. ${ }^{21-23}$ There is evidence that tiotropium bromide may have beneficial effects besides its bronchodilatory efficacy resulting in a decrease of chronic inflammation in COPD patients. ${ }^{13}$ Taken together, the present results may suggest that tiotropium bromide modulates favorably with the clinical conditions of COPD through the inhibition of neutrophil migration and activation by the suppression of IL-8 production from airway epithelial cells and lung fibroblasts. 


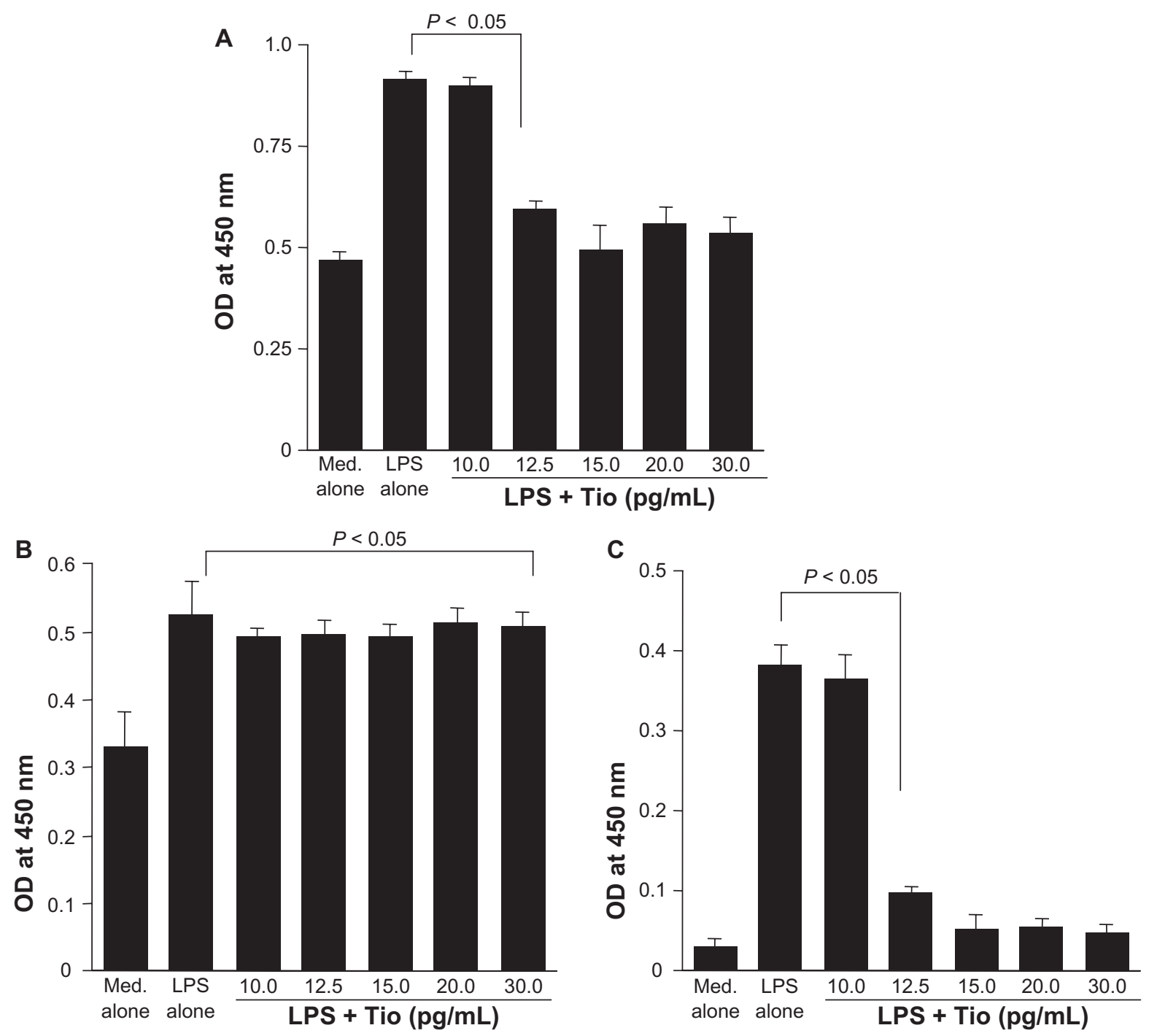

Figure 5 Influence of tiotropium bromide (Tio) on signaling protein phosphorylation in BEAS-2B cells after lipopolysaccharide (LPS) stimulation. Cells $\left(5 \times 10^{5}\right.$ cells $\left./ \mathrm{mL}\right)$ were stimulated with $1.0 \mu \mathrm{g} / \mathrm{mL}$ LPS in the presence of various concentrations of Tio for 30 minutes. Signaling protein phosphorylation was examined by ELISA. The data are expressed as the mean optical density (OD) at $450 \mathrm{~nm} \pm \mathrm{SE}$ of five different subjects. (A) c-Jun N-terminal kinase (JNK) phosphorylation; (B) extracellular-signal-related kinase (ERKI/2) phosphorylation; (C) p38 mitogen-activated protein kinases (p38 MAPK) phosphorylation.

There is much evidence that central to the recognition of LPS expression in endothelial cells is a family of transmembrane proteins known as Toll-like receptors (TLRs). ${ }^{24-26}$ Most effector cells of the immune responses, especially the innate immune system, such as monocytes and endothelial cells express TLR 2 and TLR $4 .{ }^{27}$ When LPS binds to TLR4, multiple intracellular signaling pathways are activated, including transcription factor, NF- $\kappa B$, pathway as well as MAPK. ${ }^{28}$ Three MAPK pathways, ERK, JNK, and p38 MAPK, contribute to IL-8 gene expression. ${ }^{29}$ ERK and p38 MAPK increase IL-8 gene expression in human bronchial cells. ${ }^{30}$ ERK can also activate NF- $\mathrm{KB}$ in human airway epithelial cells. ${ }^{31}$ Therefore, we then examined the possible mechanisms by which tiotropium bromide could inhibit LPS-induced IL-8 production from airway cells. The data clearly show that pretreatment of BEAS-2B cells and LFs decreased NF- $\mathrm{KB}$ activation induced by LPS stimulation. It was also observed that tiotropium bromide could suppress phosphorylation of JNK and ERK1/2, but not p38 MAPK, which was increased by LPS stimulation. On the other hand, blocking experiments using MAPK pathway inhibitors showed evidence for the phosphorylation of ERK $1 / 2$ and $\mathrm{p} 38$ MAPK, but not JNK in the production of IL-8 from BEAS-2B cells and LFs in response to LPS stimulation. Taken together, these results strongly suggest that tiotropium bromide inhibits IL-8 mRNA expression in BEAS-2B cells and LFs after LPS stimulation, which is responsible for inhibition of IL-8 production at protein levels, through the suppression of the 


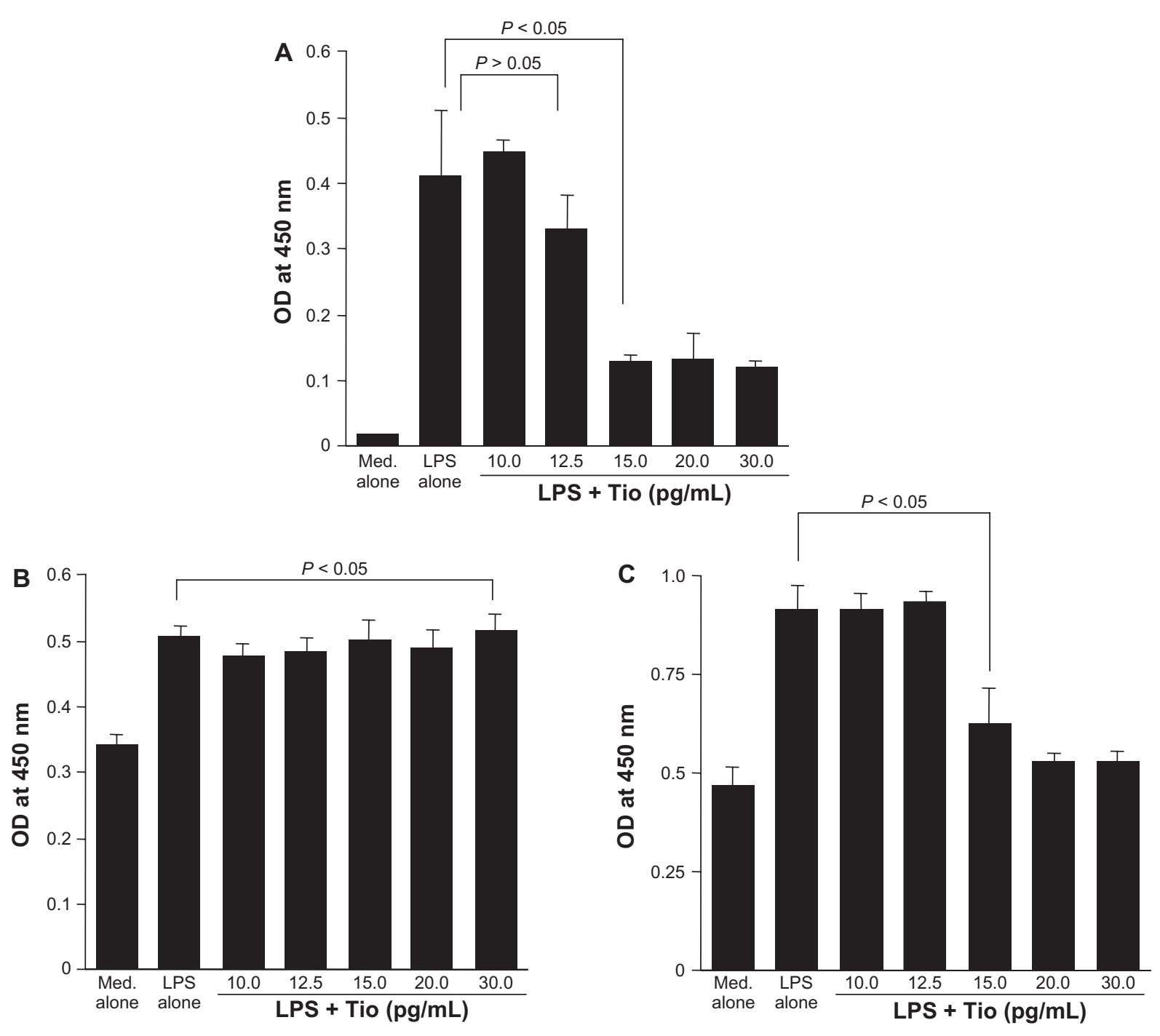

Figure 6 Influence of tiotropium bromide (Tio) on signaling protein phosphorylation in lung fibroblasts after lipopolysaccharide (LPS) stimulation. Cells $\left(5 \times 10^{5}\right.$ cells $\left./ \mathrm{mL}\right)$ were stimulated with $1.0 \mu \mathrm{g} / \mathrm{mL}$ LPS in the presence of various concentrations of Tio for 30 minutes. Signaling protein phosphorylation was examined by ELISA. The data are expressed as the mean optical density (OD) at $450 \mathrm{~nm} \pm \mathrm{SE}$ of five different subjects. (A) c-Jun N-terminal kinase (JNK) phosphorylation; (B) extracellular-signal-related kinase (ERKI/2) phosphorylation; (C) p38 mitogen-activated protein kinases (p38 MAPK) phosphorylation.

activation of signal transducers and transcription factor, especially ERK1/2 and NF- $\mathrm{KB}$. This speculation may be supported by the observation that pretreatment of $16 \mathrm{HBE}$ cells, a human bronchial epithelial cell line, with tiotropium bromide completely abolished IL-8 release induced by acetylcholine stimulation through the suppression of ERK1/2 and NF- $\kappa$ B activation. ${ }^{18}$

The activation of ERK1/2 signaling is regulated by cyclic adenosine monophosphate (cAMP), ${ }^{32}$ and elevation of cAMP levels in human bronchial epithelial cells increases IL-8 production. ${ }^{33}$ These reports may suggest that tiotropium bromide exerts the suppressive effect on the increase of cAMP by LPS stimulation in BEAS-2B cells and LFs. This speculation may be supported, in part, by the observation that muscarinic receptor antagonists, diphenidol and muscarinic toxin, ${ }^{7}$ blocked cAMP accumulation in both $\mathrm{CHO}-\mathrm{K} 1$ cells after forskolin stimulation and rat striatal slices induced by muscarinic M1 receptor stimulation. ${ }^{34,35}$ On the other hand, stimulation of the TLR4 with LPS is reported to cause the activation of proline-rich tyrosine kinase, Pyk2, which is an essential intermediate providing a link between extracellular stimuli and signaling pathways involving MAPKs. ${ }^{36}$ It is also reported that, as a result of the interaction of LPS and TLR4 on the cell surface, a signaling route is initiated via Pyk 2 and MAPKs pathway leading to the production of IL-8 through NF- $\kappa \mathrm{B}$ activation. ${ }^{26}$ These reports suggest the possibility that tiotropium bromide suppresses Pyk2 activation induced by LPS stimulation and results in the inhibition of IL-8 production through the suppression of the Pyk2-mediated signaling pathway. 

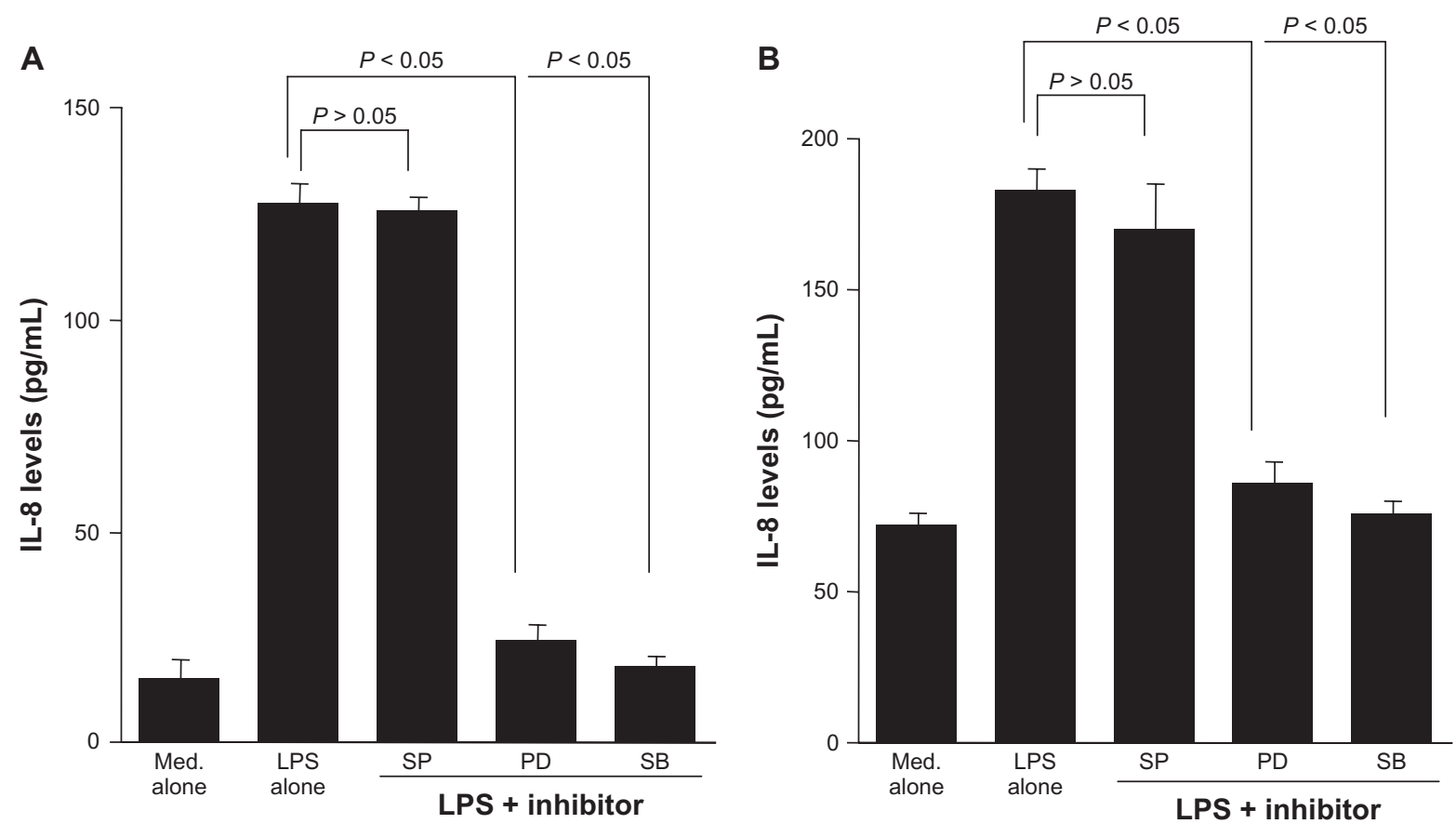

Figure 7 Influence of kinase inhibitors on IL-8 production from BEAS-2B cells $(\mathbf{A})$ and lung fibroblasts $(\mathbf{B})$ after lipopolysaccharide $(\mathrm{LPS})$ stimulation. Cells $\left(5 \times 10^{5}\right.$ cells $\left./ \mathrm{mL}\right)$ were stimulated with $1.0 \mu \mathrm{g} / \mathrm{mL}$ LPS in the presence of various concentrations of inhibitors for 24 hours. IL-8 levels in culture supernatants were examined by ELISA. The data are expressed as the mean pg/mL \pm SE of five different subjects. SP: SP-600 I25; PD: PD-98059; SB: SB-203580.

In conclusion, the present data clearly show that tiotropium bromide suppresses LPS-induced release of IL-8 from BEAS-2B cells as well as from LFs via the blockade of signaling pathways. This mechanism may possibly explain the therapeutic mode of action of tiotropium bromide on clinical conditions of patients with COPD.

\section{Acknowledgment}

The authors thank Nippon Boehringer Ingelheim Co, Ltd (Tokyo, Japan) for the kind donation of pure powder of tiotropium bromide.

\section{Disclosure}

The authors report no conflicts of interest in this work.

\section{References}

1. Konigshoff M, Kneidinger N, Eickelberg O. TGF- $\beta$ signaling in COPD: deciphering genetic and cellular susceptibilities for future therapeutic regimens. Swiss Med Wkly. 2009;139:554-563.

2. Groneberg DA, Chung KF. Models of chronic obstructive pulmonary disease. Respir Res. 2004;5:18.

3. Crapo RO, Jensen RL, Hargreave FE. Airway inflammation in COPD: physiological outcome measures and induced sputum. Eur Respir J. 2003;21(Suppl 41):19s-28s.

4. Babusyte A, Stravinskaite K, Jeroch J, Lotvall J, Sakalauskas R, Sitkauskiene B. Pattern of airway inflammation and MMP-12 expression in smokers and ex-smokers with COPD. Respir Res. 2007;8:81

5. Powrie DJ, Wilkinson TMA, Donaldson GC, et al. Effect of tiotropium on sputum and serum inflammatory markers and exacerbations in COPD. Eur Respir J. 2007;30:472-478.
6. Gosens R, Zaagsma J, Meurs H, Halayko J. Muscarinic receptor signaling in the pathophysiology of asthma and COPD. Respir Res. 2006;7:73

7. Barnes PJ. The pharmacological properties of tiotropium. Chest 2000;117(Suppl):63s-66s.

8. Rodrigo GJ, Nannini LJ. Tiotropium for the treatment of stable chronic obstructive pulmonary disease: a systemic review with meta-analysis. Pulm Pharmacol Ther. 2007;20:495-502.

9. Henkel KM, Frondorf K, Gonzalez-Mejia ME, Doseff AL, Cambronero JG. IL-8-induced neutrophil chemotaxis is mediated by Janus kinase 3 (JAK3). FEBS Lett. 2011;585:159-166.

10. Stockley RA, Bayley DL, Hill SL, et al. Assessment of airway neutrophils by sputum color: correlation with airways inflammation. Thorax. 2001;56:366-372.

11. Woolhouse IS, Bayley DL, Stockley RA. Effect of sputum processing with dithiothreitol on the detection of inflammatory mediators in chronic bronchitis and bronchiectasis. Thorax. 2002;57:667-671.

12. Singh D, Edward L, Tal-Singer R, Rennard S. Sputum neutrophils as a biomarker in COPD: findings from the ECLIPSE study. Respir Res. 2010;11:77.

13. Vacca G, Randerath WJ, Gillissen A. Inhibition of ganulocyte migration by tiotropium bromide. Respir Res. 2011;12:24.

14. Asano K, Shikama Y, Shibuya Y, et al. Suppressive activity of tiotropium bromide on matrix metalloproteinase production from lung fibroblasts in vitro. Int J Chron Obstruct Pulmon Dis. 2008;3: 781-790.

15. Keam SJ, Keating GM. Tiotropium bromide. A review of its use as maintenance therapy in patients with COPD. Treat Respir Med. 2004; $3: 247-268$.

16. Gillitzer R, Goebeler M. Chemokines in cutaneous wound healing. J Leukoc Biol. 2001;69:513-521.

17. Benelli R, Morini M, Carrozzino F, et al. Neutrophils as a key cellular target for angiostatin: implications for regulation of angiogenesis and inflammation. FASEB J. 2002;16:267-269.

18. Waugh DJ, Wilson C. The interleukin-8 pathway in cancer. Clin Cancer Res. 2008;14:6735-6741. 
19. Profita M, Bonanno A, Siena L, et al. Acetylcholine mediates the release of IL-8 in human bronchial epithelial cells by a NFKB/ERK-dependent mechanism. Eur J Pharmacol. 2008;582:145-153.

20. Qiu Y, Bandi V, Atmar RL, Hattotuwa K, Guntupalli KK, Jeffery PK. Biopsy neutrophilia, neutrophil chemokine and receptor gene expression in severe exacerbations of chronic obstructive pulmonary disease. Am J Respir Crit Care Med. 2003;168;968-975.

21. Jeffery PK. Remodeling and inflammation of bronchi in asthma and chronic obstructive pulmonary disease. Proc Am Thorac Soc. 2004;1: 176-183.

22. Andelid K, Bake B, Rak S, Linden A, Rosengren A, Ekberg-Janssen A. Myeloperoxidase as a marker of increasing systemic inflammation in smokers without severe airway symptoms. Respir Med. 2001;95: 891-897.

23. Eagan TM, Damas JK, Ueland T, et al. Neutrophil gelatinase-associated lipocalin: a biomarker in COPD. Chest. 2010;138:888-895.

24. Yoshikawa T, Dent G, Ward J, et al. Impaired neutrophil chemotaxis in chronic obstructive pulmonary disease. Am J Respir Crit Med. 2007; 175:473-479.

25. Rock FL, Hardiman G, Timans JC, Kastelen RA, Bazan JF. A family of human receptors structurally related to Drosophila Toll. Proc Natl Acad Sci U S A. 1998;95:588-593.

26. Hoffman JA, Kafatos FC, Janeway CA, Ezekowitz RA. Phylogenic perspectives in innate immunity. Science. 1999;284:1313-1318.

27. Anand AR, Cucchiarini M, Terwilliger EF, Ganju RK. The tyrosine kinase Pyk2 mediated lipopolysaccharide-induced IL-8 expression in human endothelial cells. J Immunol. 2008;180:5636-5644.

28. Faure E, Equils O, Sieling PA, et al. Bacterial lipopolysaccharide activates NF- $\mathrm{\kappa B}$ through toll-like receptor 4 (TLR-4) in cultured human dermal endothelial cells: differential expression of TLR-4 and TLR-2 in endothelial cells. J Biol Chem. 2000;275:11058-11063.
29. Kristin L, Walton W, Holt L, Sartor RB. Lipopolysaccharide activates innate immune responses in murine intestinal myofibroblasts through multiple signaling pathways. Am J Physiol Gastrointest Liver Physiol. 2009;296:G601-G611.

30. Hoffman E, Dittrich-Breiholz O, Holtmann H, Kracht M. Multiple control of interleukin-8 gene expression. J Leukoc Biol. 2002;72:847-855.

31. Li J, Johnson XD, Iazvovskaia S, Tan A, Lin A, Hershenson MB. Signaling intermediates required for NF-kappaB activation and IL-8 expression in CF bronchial epithelial cells. Am J Physiol Lung Cell Mol Physiol. 2003;284:L307-L315.

31. Dikie I, Tokiwa T, Lev S, Courtneidge SA, Schlezinger G. A role of Pyk2 and Src in linking G-protein-coupled receptors with MAP kinase activation. Nature. 1996;383:547-550.

32. Chen BC, Yu CC, Lei HC, et al. Bradykinin B2 receptor mediates NF-kappaB activation and cyclooxygenase-2 expression via the RAS/ Raf-1/ERK pathway in human airway epithelial cells. $J$ Immunol. 2004;173:5219-5228.

33. Stork PJ, Schmitt JM. Crosstalk between cAMP and MAP kinase signaling in the regulation of cell proliferation. Trends Cell Biol. 2002; $12: 258-266$.

34. Sasaki K, Manabe H. KF19514, a phosphodiesterase 4 and 1 inhibitor, inhibits TNF-alpha-induced GM-CSF production by a human bronchial epithelial cell line via inhibition of PDE4. Inflamm Res. 2004;388: 31-37.

35. Sanchez-Lemus E, Arias-Montano JA. M1 muscarinic receptors contribute to, whereas M4 receptors inhibit, dopamine D1 receptorinduced $[3 \mathrm{H}]$-cyclic AMP accumulation in rat striatal slices. Neurochem Res. 2006;31:555-561.

36. Varoli L, Angeli P, Buccioni M, et al. Synthesis and pharmacological profile of a series of 1-substituted-2-carbonyl derivatives of diphenidol: novel M4 muscarinic receptor antagonists. Med Chem. 2008;4: 121-128.
International Journal of COPD

\section{Publish your work in this journal}

The International Journal of COPD is an international, peer-reviewed journal of therapeutics and pharmacology focusing on concise rapid reporting of clinical studies and reviews in COPD. Special focus is given to the pathophysiological processes underlying the disease, intervention programs, patient focused education, and self management protocols.

\section{Dovepress}

This journal is indexed on PubMed Central, MedLine and CAS. The manuscript management system is completely online and includes a very quick and fair peer-review system, which is all easy to use. Visit $\mathrm{http}: / /$ www.dovepress.com/testimonials.php to read real quotes from published authors. 